\title{
PERILAKU PROFESIONAL GURU PROGRESIF
}

\author{
Asmuri Darma \\ Universitas Islam Negeri Sultan Syarif Kasim Riau \\ Email: asmuri@uin-suska.ac.id
}

\begin{abstract}
Teachers play a leading role and occupy a very crucial position in the world of education, especially education organized formally in both schools and madrasah. Therefore, the constitutional existence of teachers has been regulated in Law no. 14 of 2005 on teachers and lecturers. The law requires a number of teacher competencies as professional educators. Although formally the teacher is regarded as a professional educator, but in practice in the field various types and behavioral models presented by the teacher in realizing the duties and responsibilities of his profession as a teacher is mainly reflected in the learning activities in the classroom. There are behavioral behavior of teachers who are stagnant even tend to decline and there is also the behavior of teachers who experience improvement and progress. The latter is what is referred to as progressive professional behavior.
\end{abstract}

Keywords: teacher, progressive, professional behavior, competencies

\section{A. Pendahuluan}

Guru memegang peran utama dan menempati posisi yang sangat krusial dalam dunia pendidikan, khususnya pendidikan yang diselenggarakan secara formal baik di sekolah maupun madrasah. Guru sangat menentukan keberhasilan peserta didik, terutama dalam kaitannya dengan proses pembelajaran. Guru merupakan komponen yang paling berpengaruh terhadap terciptanya proses dan hasil pendidikan yang berkualitas. Oleh karena itu pekerjaan mendidik, membimbing dan mengajar merupakan pekerjaan profesional yang tidak mungkin dapat dilakukan oleh sembarang orang yang berprofesi lain atau bukan sebagai guru.

Menyadari pentingnya peran guru dalam pendidikan, maka pemerintah dan DPR melalui UU No. 14 Tahun 2005 tentang guru dan dosen, telah menetapkan bahwa guru adalah pendidik profesional dengan tugas utama mendidik, mengajar, membimbing, mengarahkan, melatih, menilai, dan 
mengevaluasi peserta didik pada pendidikan anak usia dini jalur pendidikan formal, pendidikan dasar, dan pendidikan menengah. ${ }^{1}$

Untuk dapat melaksanakan tugasnya secara profesional maka dituntut sejumlah kompetensi yang harus dikuasai oleh seorang guru. Kompetensi tersebut meliputi kompetensi pedagogik, kompetensi kepribadian, kompetensi sosial, dan kompetensi profesional yang diperoleh melalui pendidikan profesi. Oleh sebab itu, dalam peraturan pemerintah dipersyaratkan pula bahwa untuk memenuhi tuntutan profesionalitas guru, seorang guru harus berpendidikan S1 atau D4 dalam bidang pendidikan. Begitu juga dengan program setifikasi guru sebagai upaya pemerintah dalam merealisasikan guru yang profesional. ${ }^{2}$

Pemerintah sejak tahun 2007 hingga saat ini telah dan masih melakukan program sertifikasi guru bagi guru-guru yang ada di negeri ini. Karena itu dapat diperkirakan hingga saat ini sebagian besar guru-guru tersebut telah lulus sertifikasi dan telah mendapatkan sertifikat pendidik. Artinya, secara formalitas-akademis, guru-guru tersebut adalah orang-orang yang memiliki sejumlah kompetensi yang dipersaratkan sebagai pendidik profesional. Selain telah memiliki latar belakang pendidikan $\mathrm{S} 1{ }^{3}$ guru-guru madrasah pada umumnya juga telah mengikuti berbagai pelatihan, workshop, seminar, lokakarya dan sebagainya yang berkaitan dengan profesi mereka sebagai guru. ${ }^{4}$

Dengan demikian, maka secara teoritis dapat dikatakan bahwa guru-guru madrasah dipandang telah memiliki persyaratan profesional terkait dengan tugas dan tanggung jawab mereka sebagai guru. Namun realitanya, ketika dilihat lebih jauh di lapangan (sekolah) menunjukkan berbagai potret yang dipresentasikan oleh perilaku profesional guru khususnya berkaitan dengan pelaksanaan kegiatan pembelajaran di dalam kelas. Sejumlah kompetensi yang dipersyaratkan sebagai tenaga profesional

${ }^{1}$ UU No. 14 Tahun 2005 tentang Guru dan Dosen, Pasal 1 ayat 1.

${ }^{2}$ Undang-Undang Guru dan Dosen Bab IV Pasal 8 bahwa guru wajib memiliki kualifikasi akademik, kompetensi, sertifikat pendidik, sehat jasmani dan rohani, serta memiliki kemampuan untuk mewujudkan tujuan pendidikan nasional. Lihat Undang-Undang Guru dan Dosen.

${ }^{3}$ Mengacu pada kriteria yang ada, seorang guru dapat dikatakan sebagai seorang profesional sejatinya apabila dia memiliki latar belakang pendidikan sekurang-sekurangnya setingkat sarjana. Dalam Undang-Undang No. 14 Tahun 2005 disebutkan bahwa untuk dapat memangku jabatan guru minimal memiliki kualifikasi pendidikan D4/S1. Lihat UU. RI. No. 14 Tahun 2005 tentang Guru dan Dosen.

${ }^{4}$ Para guru selalu aktif dalam mengikuti pertemuan-pertemuan KKM (Kelompok Kerja Madrasah), pertemuan KKG, MGMP PAI. Mereka juga secara aktif selalu mengikuti pelatihan-pelatihan yang berkaitan dengan kependidikan baik yang diadakan oleh Kemenag maupun Kemendiknas dalam rangka meningkatkan profesionalitas mereka sebagai guru. Wawancara dengan Syafrizal dan Mahdar, Kepala Madrasah dan Kepala Tata Usaha Madrasah Mu’allimin Kubu Rokan Hilir. 
dalam implementasi dan aplikasinya di lapangan ditunjukkan oleh perilaku guru. Perilaku atau tindakan guru tersebut sebagai manivestasi dari profesionalitasnya dalam praksisnya tentu tidak dapat dipisahkan dari kondisi objektif seluruh komponen pendidikan dan pembelajaran yang mengitarinya.

Dalam realitanya tidak sedikit kondisi objektif itu yang kurang menunjang profesionalitas guru. Maka pada titik inilah memunculkan problem akademik, yaitu bagaimana sebenarnya sikap guru dalam memandang dan memposisikan kondisi objektif tersebut?, bagaimana pula implikasinya terhadap perilaku profesional mereka sebagaimana tercermin dalam kegiatan pembelajaran yang dilaksanakan di dalam kelas? Di sinilah urgensi perilaku profesional guru yang progresif, di mana kondisi dan situasi yang ada tidak menjadi hambatan, bahkan kinerja profesionalnya sebagai guru cenderung mengalami peningkatan dan kemajuan.

Dalam konteks inilah, artikel yang didasarkan pada hasil penelitian lapangan ini dihadirkan sebagai upaya menjawab problem akademik di atas, yaitu dengan mengetengahkan apa dan bagaimana perilaku profesional guru yang progresif dan apa saja yang menjadi krakteristik dari perilaku profesional guru yang progresif.

Dalam kajian ini, perilaku profesional guru dimaksudkan sebagai tindakan guru atau aktivitas gurukhususnya dalam kegiatan pembelajaran di kelas yang meliputi; (1) perilaku guru berkaitan dengan perencanaan pembelajaran, (2) perilaku guru berkaitan dengan pelaksanaan pembelajaran di dalam kelas, (3) perilaku guru berkaitan dengan pengembangan profesinya sebagai guru.

\section{B. Perilaku Profesional Guru Progresif}

Sesuai dengan pengertiannya, progresif berasal dari bahasa Inggris yaitu progress yang mempunyai arti kemajuan. ${ }^{5}$ Dalam Kamus Besar Bahasa Indonesia progresif bermakna ke arah kemajuan, berhaluan ke arah perbaikan keadaan sekarang, bertingkat-tingkat naik. ${ }^{6}$ Hal ini juga hampir sama dalam kamus ilmiah populer. ${ }^{7}$ Pada

${ }^{5}$ John M. Echols dan Hassan Shadily, Kamus Inggris-Indonesia, An English-Indonesian Dictionary, diedit dan direvisi oleh John U. Wolff dan James T. Collins bekerjasama dengan Hassan Shadily, (Jakarta: PT. Gramedia, 1992), Cet. XX., hlm. 450.

${ }^{6}$ Tim Penyusun Kamus Pusat Pembinaan dan Pengembangan Bahasa, op.cit, hlm. 189.

${ }^{7}$ Progresif berasal dari kata "progres" yang berarti: kemajuan, maju sedangkan progresif sendiri diartikan sebagai berhasrat maju, selalu lebih maju, meningkat. Sedangkan orang yang mempunyai sifat progresif (orang yang berhasrat dan selalu berusaha untuk maju) disebut sebagai progresivis. 
prinsipnya progresif merupakan kata yang mempunyai makna mendalam bagi diri seseorang demi kemajuan dan perbaikan dalam segala hal.

Dengan berpijak pada makna kata di atas, maka perilaku guru yang cenderung mengalami kemajuan dan peningkatan ke arah lebih baik dapat dikatakan sebagai perilaku progresif. Kemajuan tersebut tidak hanya dalam bentuk perilaku secara fisikdan lebih bersifat teknis seperti tercermin dalam pembuatan RPP, penerapan berbagai model dan strategi pembelajaran modern, tetapi juga tergambar dari cara pandang dan pola pikir mereka yang lebih mengedepankan aspek perubahan dan kemajuan. Dalam arti cara pandang yang selalu berorientasi pada kemajuan dan perbaikan dalam segala hal. Dan semua itu hanyalah bertujuan satu yaitu demi kemajuan, serta kejayaan pendidikan.

Sebagaimana tampak pada profil Syafrizal, salah seorang guru Madrasah Mu'allimin yang saat ini sedang melanjuntkan studi S3 di Program Pascasarjana UIN Suska Riau yang ada di Pekanbaru. Dalam sebuah wawancara ia mengatakan:

"Saya sudah lebih kurang 12 tahun mengabdikan diri di Madrasah Mu'allimin ini dan alhmdulillah sudah sertifikasi. Motivasi saya adalah selain tanggung jawab keluarga, karena yayasan Mu'allimin yang menyelenggarakan pendidikan ini adalah milik keluarga, juga didorong oleh panggilan jiwa untuk kemajuan anak-anak di daerah ini. Begitu saya menyelesaikan pendidikan S2 di UKM Kuala Lumpur Malasia pada tahun 2004, saya pun memantapkan niat saya untuk terlibat secara aktif dalam penyelenggaraan dan pengelolaan pendidikan di Madrasah Mu'allimin ini. Sebagai guru dan salah salah satu pimpinan di madrasah ini, saya selalu menganjurkan kepada para guru untuk selalu meningkatkan kompetensi mereka sebagai guru, karena tantangan kita selaku guru ke depan semakin kompleks, tuntutan akan peningkatan mutu dan kualitas lulusan semakin tinggi, maka guru tidak bisa tidak, harus berupaya memacu diri mereka demi eksistensi madrasah ini yang alhamdulillah dari tahun ke tahun mengalami peningkatan. Saya sendiri saat ini sedang kuliah S3 pada Program Pascasarjana UIN Suska Riau. Jadi kalau ditanya apa yang menjadi motivasi saya, ya dorongan yang begitu kuat dari dalam diri saya untuk lebih maju dan berharap yang saya lakukan ini menjadi inspirasi dan motivasi bagi guru-guru lain dan anak-anak di madrasah ini."

Dari ungkapannya di atas, selain rasa tanggung jawab "kekeluargaan" juga adanya rasa tanggung jawab moral dan panggilan hati yang memantapkan niatnya untuk mengabdikan dirinya di lembaga pendidikan ini. Walaupun saat itu ia telah berpendidikan S2 pada Program Pascasarjana UKM Malaysia, secara formal-

\footnotetext{
${ }^{8}$ Syafrizal, Wawancara, Tanggal 15 Februari 2016
} 
administratif ia memiliki kesempatan untuk menjadi dosen di beberapa perguruan tinggi yang ada di Kota Pekanbaru, namun ia lebih memilih untuk menjadi guru dan mengbdikan dirinya di madrasah yang berada di kampungnya (wilayah kecamatan) yang relatif jauh dari ibukota kabupaten dan Provinsi Riau.

Sebagai guru yang progresif, sekalipun berada di daerah pedesaan dengan sosio kultural masyarakat yang masih dominan tradisional, tapi semangatnya untuk maju dan terus belajar tidak pernah surut dan berhenti. Pengetahuan dan wawasannya tidak ingin tertinggal dan kalah dengan pengetahuan dan wawasan orang (guru) di kota. Ia senantiasa terus mencari perkembangan terbaru terutama menyangkut pendidikan dengan mengakses televisi melalui parabola dan internet melalui jaringan Telkomsel yang terdapat hampir di seluruh pelosok negeri ini.

Dewasa ini dengan kemajuan teknologi informasi yang sudah merata hampir di setiap pelosok negeri ini bahkan daerah terpencil sekalipun. Maka sebenarnya tidak ada alasan terutama bagi seorang guru untuk ketinggalan informasi dan wawasan. Banyak cara bagi guru untuk meng-up date pengetahuan. Membaca berbagai bacaan yang ada, sering berdiskusi, bertanya dan sebagainya. Berpulang lagi pada krakter masing-masing individu itu sendiri. Karena menambah pengetahuan, wawasan dan terus belajar bagi seorang guru berkaitan dengan spirit, motivasi, tradisi dan mentalitas. Mutu pendidikan yang dinilai dari prestasi belajar peserta didik sangat di tentukan oleh guru, guru adalah pemimpin pembelajaran, fasilitator, dan sekaligus merupakan pusat inisiatif pembelajaran. Karena itu, guru harus senantiasa mengembangkan diri secara mandiri serta tidak bergantung pada inisiatif kepala sekolah maupun supervisor. ${ }^{9}$

Semangatnya untuk maju yang penulis rasakan juga terlihat dari kegemarannya bertanya dan berdiskusi tentang berbagai persoalan, khususnya tentang bagaimana meningkatkan mutu dan kualitas pendidikan di madrasah. ${ }^{10}$ Hampir setiap malamnya selama penulis berada di lokasi penelitian selalu berbincang-bincang dan terlibat diskusi tentang berbagai hal, terutama tentang agama dan persoalan-persoalan pendidikan. Dapat dikatakan ia sangat agresif dalam menambah pengetahuan dan wawasan. Salah satu ungkapan beliau yang sangat berkesan bagi penulis adalah "kita boleh tinggal di

\footnotetext{
${ }^{9}$ Dedi Supriadi, Mengangkat Citra dan Martabat Guru, (Yogyakarta: Adicita Karya Nusantara, 1998), hlm. 178.

${ }^{10}$ Penulis selama berada di lokasi penelitian tinggal bersama di kediaman Bapak Syafrizal, ia dengan senang hati menerima penulis dan tinggal di rumahnya.
} 
kampung seperti Kubu ini (hanya kota kecamatan) yang sangat jauh dari kota kabupaten dan provinsi, tapi pengetahuan dan wawasan kita jangan sampai tertinggal dan kalah dengan pengetahuan dan wawasan orang di kota."

Ia tidak menunggu datangnya pengetahuan baru, tapi secara aktif berusaha mencari perkembangan terbaru terutama menyangkut pendidikan melalui media elektronik seperti televisi parabola dan internet yang disiapkan melalui jaringan Telkomsel. Nampaknya sifat ini yang membuatnya terlihat segar dan berwibawa serta disegani di kalangan guru lainnya dan juga di masyarakat.

Dalam pengamatan penulis, tidak pernah ia kelihatan tidak siap untuk mengajar, bahkan beliau selalu stand by dan siap menggantikan guru yang kebetulan berhalangan hadir. Dengan banyaknya informasi dan wawasan yang dimiliki membuat beliau lebih kreatif-inovatif dalam mengembangkan materi pembelajaran. Strategi dan metode yang diterapkan lebih bervariasi, sehingga pembelajaran menjadi tidak monoton dan membuat para siswa merasa senang belajar dengan beliau. Salah seorang alumni Madrasah Mu'allimin yang penulis jumpai mengatakan:

"Bapak Syafrizal salah seorang guru yang telah menjadi inspirasi dan motivasi khususnya bagi saya agar saya bisa lebih maju terutama dalam hal pendidikan saya. Selama belajar dengannya, ia selalu memberi dorongan dan motivasi kepada anak didiknya untuk terus belajar dan belajar demi kesuksesan hidup, baik di dunia maupun di akherat. Sampai sekarang saya masih teringat saat beliau mengajar beliau selalu mengatakan " dengan ilmu hidup menjadi mudah, dengan agama hidup menjadi lebih terarah." Ia juga selalu mengungkapkan hadits Nabi SAW bahwa barang siapa ingin kebahagiaan hidup di dunia hendaklah dengan ilmu, barang siapa yang ingin kebahagiaan di akherat hendaklah dengan ilmu, dan barang siapa menghendaki kebahagiaan dunia akherat hendaklah dengan berilmu. Dalam mengajar, Bapak Syafrizal lebih bersifat demokratis dan lebih terbuka kepada anak didiknya, ia selalu mendorong kami untuk bertanya. Jawaban atas pertanyaan yang disampaikan menunjukkan luasnya pengetahuan dan wawasan yang dimilikinya, sungguh hal inilah yang menjadi spirit dan inspirasi khususnya bagi saya, membuat saya bertekad untuk melanjutkan pendidikan saya diperguruan tinggi, walau secara materi saya tergolong tidak mampu. Tapi ceritanya tentang orang-orang sukses yang berasal dari keluarga tidak mampu secara materi telah menumbuhkan dan membangkitkan semangat saya."11

\footnotetext{
${ }^{11}$ Susanto A. Yamin, juga pernah menjadi mahasiswa dan kuliah dengan penulis di Jurusan PAI UIN Suska Riau. Sepengetahuan penulis dia mahasiswa yang aktif dan kreatif, selama menjadi mahasiswa ia sangat mandiri, tinggal di masjid dan mengajar mengaji secara privat ke rumah-rumah untuk biaya hidup dan kuliahnya. Wawancara, Pekanbaru pada tanggal 11 Maret 2016.
} 
Guru yang progresif, mengajar bukan hanya sekedar untuk mencapai sejumlah kompetensi yang telah ditetapkan dan dirumuskan ke dalam sejumlah indikator, tetapi menjadikan mengajar sebagai bagian dari totalitas pembinaan demi kesuksesan anak didiknya dalam mengarungi samudera kehidupan. Oleh karena wawasannya yang luas, maka yang diajarnya pun menjadi sangat terkesan dan sangat senang belajar dengannya. Padahal, Syafrizal mengajarkan pelajaran yang sulit bagi kami memahaminya, yaitu pelajaran bahasa Arab. Namun cara mengajarnya sangat enak, di mana beliau selalu mengaitkan materi pelajaran bahasa Arab yang rumit dengan realitas nyata yang kami temui dalam kehidupan sehari-hari. Demikian ungkap beberapa orang siswa Madrasah Aliyah yang penulis wawancarai. ${ }^{12}$ Belajar hanya akan efektif bila mampu mengaitkan secara langsung dengan kebutuhan yang muncul di era baru (realitas).

Pada pola progresif makna belajar diartikan sebagai pembangunan gagasan/pengetahuan oleh peserta didik sendiri selain peningkatan keterampilan dan pengembangan sikap positif. Guru belum dikatakan mengajar kalau peserta didik belum belajar. Artinya, guru baru mengajar kalau konsep materi yang disajikan dapat menjadi bagian dari 'struktur kognitif' peserta didik. Untuk mencapai tujuan ini, guru tidak cukup hanya berceramah dari menit pertama sampai menit terakhir kegiatan pembelajaran. Akan tetapi peserta didik perlu dilibatkan secara aktif dalam kegiatan pembelajaran, seperti dalam bentuk pengujian, eksprimen (percobaan atau penelitian sederhana) ataupun pengalaman riil peserta didik. Lester D. Crow dan Alice Crow mengatakan Learning is an active process that needs to be stimulated and guided toward desirable out comes (Belajar adalah proses aktif yang membutuhkan suatu rangsangan dan panduan kearah yang di inginkan). ${ }^{13}$

Dalam hal ini, Dewey menekankan pada penerapan metode langsung, spesifik dan pengalaman-pengalaman yang mengesankan, sehingga menumbuhkan minat belajar yang besar di kalangan anak didik. Bagi Dewey, minat anak mampu menyediakan percikan bunga api, di mana tanpa itu proses belajar tidak akan tersulut. Sebab, proses belajar hanya akan terjadi apabila siswa merasakan bahwa suatu aktivitas itu berharga dan pada gilirannya menimbulkan minat yang besar baginya untuk belajar. Di sinilah

\footnotetext{
${ }^{12}$ M. Bulyan, Ristawani, Halimah dan M. As'ad, Siswa Kelas XI Madrasah Aliyah Mu'allimin, Wawancara, Tanggal 15 Februari 2016

${ }^{13}$ Lester D. Crow dan Alice Crow, Educational Psychology, (New York: American Book Company, 1958), hlm. 225.
} 
peran guru untuk senantiasa berusaha menumbuhkan minat belajar yang tinggi di kalangan anak didik. Menurut Dewey, antara minat dan usaha bukanlah dua perkara yang saling berlawanan, tetapi satu sama lain saling melengkapi. ${ }^{14}$ Pengetahuan dalam tradisi progresif tidak muncul melalui penerimaan informasi, sebagai substansi abstrak yang asal ditransferkan dari guru kepada murid. Pengetahuan merupakan instrumen untuk mengatur pengalaman. ${ }^{15}$

Perilaku guru sebagai pendidik lebih diposisikan sebagai mitra peserta didik, disiplin permisif, berdialog dengan pikiran kritis,melakukan dialektika budaya lama dengan nilai-nilai budaya modern, memberikan kesempatan kreatif, berproduksi, dan berperilaku sehari-hari yang positif terhadap peserta didik. Bahkan pembejaran yang baik sebagai bagian dari pendidikan selain memerlukan proses dan alasan rasional intelektual juga terjalin alasan yang bersifat moral. Untuk yang terakhir ini, sebagai bentuk dan perhatian terhadap pentingnya internalisasi nilai-nali dalam proses pembelajaran. Sebagaimana dalam pandangan al-Abrasyi yang cenderung mengutamakan nilai-nilai moral, etika, akhlak dan fadilah sebagai bagian esensial dari proses pembelajaran. Seperti memberikan sugesti kepada peserta didik melalui ceritacerita (story) tentang orang-orang saleh dan orang-orang yang sukses, memberikan nasihat dan sebagainya. ${ }^{16}$

Dalam konteks ini, Syafrizal dalam mendidik juga menggunakan metode bimbingan dan teladan. Metode ini sangat melekat dalam dirinya, selain sebagai guru di madrasah ia juga ditunjuk oleh masyarakat sebagai ketua MUI (Mejlis Ulama Indonesia) Kecamatan Kubu Rokan Hilir. Berdasarkan pengamatan penulis selama berada di lokasi penelitian, terlihat Syafrizal begitu tiba waktu shalat zuhur, ia langsung mengingatkan dan mengajak anak didiknya untuk bersama-sama melaksanakan sholat berjamaah di mushalla madrasah. Selesai shalat diikuti dengan zikir dan berdoa bersama-sama, setelah itu ia berdiri dan selama lebih kurang 10 menit memberikan tausiah berupa nasehat-nasehat yang lebih ditujukan kepada anak didiknya agar berakhlak mulia, dan memiliki semangat yang tinggi dalam belajar dan menuntut ilmu.

\footnotetext{
${ }^{14}$ Lihat Abd. Rachman Assegaf, Filsafat Pendidikan Islam: Paradigma Baru Pendidikan Hadhari Berbasis Integratif-Interkonektif, (Jakarta: PT. Raja Grafindo, 2011), hlm. 119.

${ }^{15}$ Ibid., hlm. 120.

${ }^{16}$ Ibid., hlm. 122.
} 
Perilaku guru progresif lainnya dapat dilihat pada profil Wan Sri Suryanti, Selain sebagai guru, dia dipercaya oleh Yayasan menjadi kepala MI (Madrasah Ibtidaiyah) di Madrasah ini sejak tahun 2012 sampai sekarang. Dalam wawancara dengan penulis, dia mengatakan bahwa motif utamanya menjadi guru di madrasah ini adalah panggilan jiwa demi masa depan anak-anak di daerah ini. Pandangannya yang menyatakan bahwa pendidikan akan terus mengalami perubahan seiring dengan perkembangan dan tuntutan zaman, dan ini sekaligus sebagai tantangan bagi guru untuk terus menempa diri, meningkatkan profesionalitasnya. Selain itu, saat ini keberadaan sekolah-sekolah umum lainnya yang sudah banyak berdiri di daerah ini, mendorongnya untuk selalu berupaya meningkatkan mutu dan kualitas pendidikan, meningkatkan profesinya sebagai guru merupakan keniscayaan baginya, hal inilah di antaranya yang mendorong nya untuk melanjutkan studinya ke jenjang S2. Saat ini gelar magister dalam bidang Manajemen Pendidikan Islam (M.Pd.I) pada Program Pascasarjana UIN Suska Riau telah berhasil diraihnya.

Sesuai dengan pengertiannya, progresif juga berarti keinginan untuk maju. Dengan demikian, perilaku profesional guru yang progresif juga berarti perilaku guru yang memiliki keinginan (determinasi) untuk selalu bergerak ke depan menuju peningkatan mutu dan kualitas pendidikan dan kesediaannya untuk selalu mereformasi diri khususnya di bidang yang berkaitan dengan keprofesiannya termasuk wawasan keilmuannya.

Implikasi dari semangat belajar, usaha yang giat untuk menambah pengetahuan dan wawasan sebagaimana ditampilkan oleh profil guru Wan Sri Suryanti di atas, adalah tumbuhnya kepercayaan dalam diri siswa yang semakin besar terhadap guru. Selain itu, juga akan semakin meningkatkan respect mereka terhadap gurunya. Mereka menyaksikan sendiri bagaimana guru mereka masih saja tekun dan giat untuk belajar. Hal inilah pada gilirannya mampu menjadi spirit dan inspirasi bagi mereka untuk lebih maju sebagaimana guru mereka.

Sekolah/madrasah dapat berhasil apabila didukung oleh kualitas guru yang profesional. Menjadi guru profesional berarti menjadi guru yang tidak pernah berhenti belajar, demikian ungkap Amstrong. ${ }^{17}$ Aset terbesar dan paling bernilai di sebuahsekolah/madrasah adalah guru yang berkualitas. "Sebaik apapun kurikulumnya,

\footnotetext{
${ }^{17}$ Thomas Amstrong, Awakening Genius ......, 177.
} 
sulit berhasil apabila tidak dijalankan dengan strategi pembelajaran yang menarik, menyenangkan, dan mampu menginspirasi anak didiknya."18 Guru merupakan faktor yang sangat mempengaruhi berhasil tidaknya kegiatan pembelajaran di kelas, dan karenanya guru selain menguasai sejumlah kompetensi yang dipersyaratkan, guru juga dituntut untuk lebih kreatif dan inovatif dalam merealisasikan penguasaannya terhadap kompetensi tersebut. Kreatif dan inovatif sangat terkait dengan luasnya wawasan yang dimiliki oleh seorang guru.

Implikasi lain dari tumbuhnya rasa kepercayaan dan respect di kalangan anak didik terhadap gurunya mendorong timbulnya kedekatan, keintiman dan ikatan relasi guru dan siswa dengan harmonis. Relasi yang lebih ideal terbangun antara guru dengan siswanya. Dalam hal ini, penulis menyaksikan sendiri pada jam-jam istirahat ada saja siswa yang mendatangi meja/ruangan Sri Suryanti. Saat dikonfirmasi mengapa siswa selalu menjumpainya, "macam-macam sajo pak yang mereka tanyokan kepada saya, ado yang bertanyo tentang materi pelajaran yang belum dipahami, ado yang nak minto izin pulang ke rumahnyolah sebentar, kalau ado teman mereka yang sakitpun jugo selalu melapornyo ke saya, sampai-sampai kalau mereka punya masalah dengan pelajaran lainyapun kadang-kadang jugo ke saya mereka meminta pendapat atau solusinyo, ya begitulah modelnyo anak-anak kami ini pak," ungkap Wan Sri Suryanti. Mungkin semua ini karena mereka merasa dekat dengan ibu, kata penulis kepadanya. Memang pak, selama ini baik di dalam maupun di luar kelas saya selalu berusaha untuk memahami watak dan karakteristik anak yang sangat heterogen karena itu saya perlakukan mereka dengan pendekatan emosional/ kejiwaan. Di dalam kelas saat memulai pelajaran terlebih dahulu saya meminta pendapat mereka tentang strategi dan metode belajar apa yang mereka inginkan dan saya sangat jarang berlaku otoriter atau bersifat memaksa kepada mereka. Akibatnya yang saya rasakan anak-anak lebih nyaman, tidak dalam kondisi tertekan saat mengkuti pelajaran dengan saya, di antara mereka yang masih malu-malu atau kurang percaya diri itulah kadang mereka menjumpai saya di luar kelas untuk menanyakan yang belum dipahaminya. Demikian ungkap Wan Sri Suryanti kepada penulis. ${ }^{19}$

\footnotetext{
${ }^{18}$ Munif Chatib, Sekolahnya Manusia, Sekolah Berbasis Multiple Intelligences di Indonesia, (Bandung: PT Mizan Pustaka, 2009), hlm. 109.

${ }^{19}$ Wan Sri Suryanti, Wawancara, Tanggal 16 Februari 2016
} 
Jika ditelaah lebih jauh, model relasi ini selaras dengan konsep humanistic education dan pendidikan berbasis kompetensi (education base competency) yang menekankan kepada pengembangan martabat manusia yang bebas membuat pilihan yang berkeyakinan. Humanistic education merupakan sebuah konsep klasik yang bersifat global, tetapi beberapa prinsip dasarnya diambil para ahli pendidikan untuk dijadikan sebuah sistem pendekatan pembelajaran. Pendidikan humanistik adalah peranan guru yang lebih banyak menjadi pembimbing dari pada pemberi ilmu pengetahuan kepada siswa dirinya. Di samping itu, konsep pendidikan humanistik juga menitik beratkan pada upaya membantu siswa agar dapat mencapai perwujudan dirinya (selfrealization) sesuai dengan kemampuan dasar dan krakteristik yang ada pada dirinya. $^{20}$

Secara teoritis, tugas guru bukan sekedar menerangkan hal-hal yang terdapat dalam buku teks, tetapi mendorong, menginspirasi, memotivasi dan membimbinganak didik dalam usaha mereka mencapai tujuan yang diinginkan. Seorang guru progresif memahami bahwa setiap individu berbeda satu sama lainnya dan masing berkembang menurut pola dan caranya sendiri.

Hal yang kurang lebih sama juga terdapat pada pribadi Pauh, seorang yang bukan asli penduduk di daerah ini yang saat ini selain sebagai guru juga menjabat sebagai Wakil Kepala MTs bidang kurikulum. Pengalamannya pernah mengajar di salah satu SMP di Sumatera Utara yang didominasi oleh guru-guru dan murid-murid yang beragama Kristen, tampaknya menjadi energi dan spirit transformatif, telah melahirkan sebuah tekad untuk mendidik, membimbing dan mencerdaskan anak-anak umat Islam khususnya di madrasah ini untuk lebih baik (maju). Menurutnya, anak-anak umat Islam harus lebih maju dalam segala hal, tidak hanya dalam bidang keagamaan saja tetapi juga dalam bidang lainnya. Karena itu, dia sangat mendukung kegiatan-kegiatan ekstra kurikuler non keagamaan yang diprogramkan di madrasah ini, seperti; kegiatan olahraga, kesenian, kepramukaan dan lain-lain. ${ }^{21}$

Tekad yang bulat dan keinginan yang kuat terlihat dari perasaan senang dan penuh keceriaan dalam mendidik, membimbing dan mengajar anak didik dalam

\footnotetext{
${ }^{20}$ Yatim Riyanto, Paradigma Baru Pembelajaran, (Jakarta: Kencana Prenada Media Grouponi, 2010), hlm. 140.

${ }^{21}$ Pauh, Wawancara, Tanggal 16 Februari 2016
} 
kesehariannya di madrasah, seperti yang diungkap beberapa orang siswa Madrasah Mu'allimin berikut ini:

"Kami sangat senang belajar dengan Ustazdah Pauh, ia mengajar mata pelajaran
Akidah Akhlak. Ustazdah selalu tampil ceria dan semangat saat mengajar, kami
yang tadinya sudah mulai merasa letih karena sudah jam terakhir pelajaran, tapi
Ustazdah bisa menumbuhkan kembali semangat belajar kami, terkadang
sebelum memulai pelajaran Ustazdah mengajak kami untuk bernyanyi bersama
lagu-lagu Islami, terkadang menyuruh kami untuk mengubah posisi tempat
duduk, terkadang Ustazdah mengadakan game (permainan). Kami pun jadi
semangat untuk mengikuti pelajaran dengan Ustazdah Pauh. Bahasanya yang
lemah lembut dan murah senyum kepada kami serta antusiasnya dalam
mengajari kami, membuat kami merasa nyaman dan bersemangat untuk
mengikuti kegiatan pembelajaran dengan Ustazdah Pauh."22

Hal senada juga diungkap oleh Mahdar, Kepala Tata Usaha Madrasah Mu'allimin, menurutnya, Pauh salah seorang guru senior yang sudah lama mengabdikan dirinya di madrasah ini lebih kurang 13 tahun. Selain sebagai guru, beliau juga dipercayakan sebagai Wakil Kepala bidang kurikulum. Beliau selalu tampil ceria dan semangat dalam mengajar anak-anak, sehingga anak-anak pun merasa nyaman dan senang belajar dengannya. ${ }^{23}$

Yatim Rianto mengutip pendapat Robert H. Davies bahwa salah satu prinsip dalam pembelajaran adalah prinsip menyenangkan. Anak didik lebih suka terus belajar jika proses pembelajaran yang dilaksanakan sebagai sesuatu yang menyenangkannya. ${ }^{24}$ Menurutnya, bahwa prinsip-prinsip ${ }^{25}$ belajar adalah landasan berpikir, landasan berpijak dan sumber motivasi dengan harapan tujuan pembelajaran dapat tercapai dan tumbuhnya proses pembelajaran yang dinamis dan terarah. ${ }^{26}$

Peter Kline yang dikutip Hernowo dalam buku "Menjadi Guru yang Mau dan Mampu Mengajar Secara Menyenangkan" mengatakan bahwa sekolah harus menjadi ajang kegiatan yang paling menyenangkan di setiap tempat dan anak-anak akan sangat

\footnotetext{
${ }^{22}$ Fatimah, Hamidah dan Intan Pratiwi, Siswa Kelas 9 MTs Madrasah Mu'allimin, Wawancara, Tanggal 16 Februari 2016

${ }^{23}$ Mahdar, Kepala Tata Usaha Madrasah Mu'allimin, Wawancara, Tanggal 16 Februari 2016.

${ }^{24}$ Yatim Rianto, Pradigma Baru Pembelajaran, (Jakarta: Prenada Media Group, 2009), hlm. 66

${ }^{25}$ Secara etimologi kata "prinsip" berasal dari bahasa latin yang berarti dasar (pendirian, tindakan) atau sesuatu yang dipegang sebagai panutan utama (Badudu \& Zain, 2001: 1089). Dalam bahasa Inggris yaitu principle yang berarti asas atau dasar ( Peter Salim, 2010: 705). Dalam bahasa Arab yaitu mabda' yang berarti titik permulaan atau asas atau dasar (Muhammad 'Ali al-Khuli, Kamus alTarbiyah: 368). Secara istilah kata prinsip (prinsip dasar) yaitu pernyataan kebenaran universal yang sudah terbukti dengan sendirinya dengan kata lain tidak perlu lagi dibuktikan kebenarannya, lihat Dardiri A. H. 1996.

${ }^{26}$ Yatim Rianto, Op. Cit., hlm. 62
} 
cepat belajar jika mereka dibimbing untuk menemukan sendiri prinsip-prinsip belajar itu. $^{27}$ Dengan kata lain, di manapun sekolah itu berada, baik di perkotaan, daerah pinggiran, atau pedesaan, kegiatan pembelajaran harus berlangsung secara menyenangkan. Mengapa harus begitu?, karena learning is most effective when it's fun. (pembelajaran paling efektif adalah pembelajaran yang berlangsung dalam suasana yang menyenangkan).

Oleh sebab itu, pembelajaran yang menyenangkan bagi Pauh nampaknya saat ini sudah menjadi komitmennya dalam setiap melaksanakan kegiatan pembelajaran di kelas. Sebagaimana ungkapannya dalam sebuah wawancara:

"Sedikit-banyak mungkin karena masyarakatpada umumnya masih beranggapan bahwa tugas seorang guru hanya sekadar mengajar di depan kelas dan memberi tugas kepada murid. Tapi menurut saya pribadi, tugas utama seorang guru bukan hanya mengajar, tapi juga memberi contoh, menginspirasi, dan yang paling penting adalah membuat murid senang belajar serta menikmati proses belajar itu sendiri. Menurut saya tolok ukur keberhasilan seorang guru itu bukan ditentukan oleh kepala sekolah maupun orangtua, tapi justru oleh anak didiknya. Keberhasilan guru utamanya tercermin pada perubahan positif yang dialami oleh murid-muridnya. Perubahan positif itu bisa jadi macam-macam indikatornya, dari mulai pemahaman murid akan materi pelajaran, rasa antusias murid dalam mengikuti proses pembelajaran, dan yang paling penting adalah sejauh mana murid menikmati proses belajar yang dijalaninya tersebut."28

Dalam perspektif psikologis, kegembiraan mempunyai peran yang signifikan dalam mempengaruhi jiwa anak. Kegembiraan juga memberikan dampak positif pada jiwa anak yang akan melahirkan kebebasan dan kehidupan bagi jiwanya, sebagaimana juga menjadikannya siap untuk menerima perintah, anjuran dan pengarahan. ${ }^{29}$

Perilaku guru progresif tidak hanya melahirkan daya tarik dan spirit untuk kemajuan, tetapi juga berusaha menciptakan iklim pembelajaran yang menyenangkan. Perpaduan antara keduanya, yaitu perilaku dan suasana pembelajaran yang menyenangkan, akan menjadikan dimensi progresif semakin menemukan momentum untuk mengkristal dan membangun energi perubahan positif dalam diri peserta didik.

Iklim pembelajaran yang menyenangkan pada gilirannya akan menarik dan menumbuhkan minat peserta didik untuk senang dan menyukai materi pelajaran. Rasa

\footnotetext{
${ }^{27}$ Hernowo, Menjadi Guru yang Mau dan Mampu Mengajar Secara Menyenangkan, (Bandung: Penerbit MLC, 2005), hlm. 15.

${ }^{28}$ Pauh, Wawancara, 16 Februari 2016

${ }^{29}$ Muhammad Nur Abdul Hafizh Suwaid, Prophetic Parenting: Cara Nabi SAW Mendidik Anak, (Yogyakarta:Pro-U Media, 2010), hlm. 189.
} 
senang terhadap pelajaran ini menjadi modal penting dalam diri peserta didik untuk menekuni dan menggeluti pelajaran secara lebih optimal. Selain itu, rasa senang juga akan menghilangkan kejenuhan, kemalasan, acuh tak acuh, dan segala hal yang membebani pikiran. Peserta didik kemudian menjadi bergairah dan senantiasa penuh semangat dalam belajar.

Begitu juga pada profil Ramlan, seorang guru tetap yang mengajar bidang studi Fisika-Kimia di Madrasah Mu'allimin dan sudah mengabdi lebih kurang 12 tahun, menurut informasi yang diperoleh bahwa pada awal-awal dia mengajar di madrasah ini merasa terpaksa. Karena itu, pada tahun-tahun pertama dia mengajar di madrasah ini terkesan acuh tak acuh terhadap keberhasilan belajar siswa, tugas mengajar dilaksanakannya tak lebih hanya sekedar memenuhi kewajiban dan mengisi kekosongan aktivitas, bahkan tidak jarang dia tidak masuk kelas. ${ }^{30}$

Dalam pengakuannya, ia mengungkapkan bahwa sejak tahun 2007, di mana saat itu dalam sebuah acara perpisahan siswa madrasah dia sangat terharu menyaksikan ekspresi kegembiraan dan kebahagiaan para orang tua/wali murid dan merasakan ucapan terimakasih mereka yang tulus terutama kepada guru-guru madrasah karena anak-anak mereka dinyatakan lulus dalam mengikuti UN (Ujian Nasional). ${ }^{31}$ Pada tahun itu, siswa MTs Madrasah Mu'allimin dinyatakan lulus 100\% dalam ujian nasional dan mendapat predikat madrasah binaan oleh Kanwil Kemenag Provinsi Riau.

Sejak saat itulah, kesadarannya akan peran dan fungsinya sebagai guru di Madrasah Mu'allimin menjadi berubah. Dia merasakan ternyata keberadaannya sebagai guru sangat berharga dan berarti terutama bagi masyarakat daerah ini. Baginya profesi sebagai guru ternyata mendatangkan kebahagiaan yang tidak bisa diukur dengan materi. Munculnya kesadaran tersebut berimplikasi terhadap perubahan pola perilakunya sebagai guru baik secara akademik maupun secara personality. ${ }^{32}$

Secara akademik, berdasarkan pengamatan dan pengakuan sejumlah informan bapak Ramlan terlihat lebih kreatif dan inovatif dalam kegiatan pembelajaran, selalu terlibat aktif dalam mengikuti berbagai kegiatan madrasah, termasuk kegiatan dalam rangka peningkatan profesinya sebagai guru. ${ }^{33}$

\footnotetext{
${ }^{30}$ Syafrizal dan Wan Sri Suryanti, Wawancara, Tanggal 17 Februari 2016

${ }^{31}$ Ramlan, Wawancara, Tanggal 17 Februari 2016

${ }^{32}$ Ramlan, Wawancara, Tanggal 17 Februari 2016

${ }^{33}$ Mahdar, Wawancara, Tanggal 17 Februari 2016
} 
Seperti terungkap dalam pengakuannya saat wawancara dengan penulis:

"Menurut saya, tidak jarang guru terbawa emosi terutama ketika menghadapi perilaku anak didik yang "nakal," anak yang "bodoh." Dulu, saat awal mula saya mengajar di sini (Madrasaah Mu'allimin) pun demikian. Terhadap anak-anak yang "nakal" atau suka meribut (membuat keributan) saya selalu berlaku keras kepadanya, karena saya anggap anak itu keterlaluan, sering saya jewer telinganya, sering saya pukul, tapi saya memukulnya ya arah-arahan misalnya pada pantat, bukan tempat-tempat yang berbahaya. Begitu juga terhadap anak yang lambat mengerti tentang materi pelajaran yang saya jelaskan, dulunya selalu saya mengatakan anak itu bodoh. Namun, sejak beberapa tahun belakangan ini, hal itu sudah sangat jarang saya lakukan. Ini tidak terlepas dari pelatihan, ataupun seminar yang saya ikuti, menimbulkan sebuah kesadaran perlunya mengembangkan label yang lebih netral dan mereduksi label negatif tentang anak yang tadinya saya mengatakan anak itu bodoh, anak itu nakal sehingga sekarang saya menganggap bahwa anak itu sebenarnya tidak bodoh dan juga tidak nakal, hanya mengalami kelainan (yang dimaksud adalah berbeda) dengan teman-teman yang lain. Saya lebih berhati-hati dan berusaha untuk tidak terbawa emosi. Saya hampir tidak pernah lagi memberikan hukuman kepada anak-anak tersebut dengan pukulan, yang tadinya saya jewer, ya saya beri sanksi begitu saja. Anak yang suka meribut saya suruh saja maju kedepan untuk mengerjakan tugas. Anak yang sering mengganggu temannya itu terus saya ingatkan, saya beri pekerjaan yang harus diselesaikannya berkaitan dengan materi pelajaran." 34

Perubahan dan peningkatan perilaku profesionalnya sebagai guru baik penguasaan metode pembelajaran maupun penguasaan profesionalnya dalam bidang Fisika, tentu saja hal ini tidak terlepas dari latar belakang pendidikannya. Karena dilihat dari pendidikan S1nya, dia memiliki latar belakang pendidikan yang linear dengan mata pelajaran yang diajarkan tersebut yaitu Jurusan Fisika pada Fakultas Keguruan dan Ilmu Pendidikan (FKIP) Universitas Riau (UNRI). Dari pengakuan sejumlah siswa Madrasah Mu'allimin yang penulis jumpai, pada umumnya mereka mengatakan senang mengikuti pelajaran Fisika dengan Bapak Ramlan.

Dalam konteks penelitian ini, yang menarik lagi bagi penulis adalah perubahan secara personality pada diri Ramlan. Selain lebih disiplin dan lebih bertanggung jawab terhadap tugas dan profesinya sebagai guru serta keberhasilan anak didiknya, juga secara perlahan dia berusaha menyesuaikan diri baik di madrasah maupun di tengah masyarakat sebagai guru di Madrasah Mu'allimin yang dalam persepsi masyarakat dianggap sebagai seorang “ustazd.” Dalam pengakuannya ia mengungkapkan:

\footnotetext{
${ }^{34}$ Ramlan, Wawancara, Tanggal 17 Februari 2016
} 
"Saya sangat bersyukur dapat mengajar di madrasah ini, yang tadinya saya sangat awam dengan agama, begitu juga dengan praktik pengamalan agama saya rasakan sangat kurang. Namun setelah lebih kurang tiga tahun saya menjadi guru di madrasah ini, secara bertahap saya mulai akrab dengan agama dan berusaha untuk meningkatkan pengamalan ajaran agama. Menjadi guru di madrasah ini telah membangun kesadaran agama dalam kehidupan saya. Belakangan saya menyadari mungkin inilah cara Allah memberikan "hidayah-Nya" kepada saya. Inilah yang menjadi motivasi saya dan membuat saya untuk bertahan mengabdikan diri di lembaga pendidikan ini, walau pun dengan honor secukupnya, tapi penuh berkah. ${ }^{35}$

Menjadi guru di madrasah telah menumbuhkan kesadaran agama dan mendorongnya untuk mengamalkan nilai-nilai dan ajaran agama dalam kehidupan sehari-hari, termasuk dalam melaksanakan tugas dan tanggung jawabnya sebagai guru. Karena itulah dalam kegiatan pembelajaran di kelas, ia tidak hanya terfokus pada mata pelajaran yang diajarkannya, tetapi juga memberikan nasihat-nasihat agama kepada anak didik. ${ }^{36}$ Baginya menjadi guru bukan hanya sekedar mengajarkan anak didik dengan sejumlah ilmu pengetahuan, namun yang lebih penting lagi adalah bagaimana mendidik dan membimbing agar anak didik menjadi pribadi yang baik.

Kemampuan penyesuaian secara personality telah menumbuhkan kesadaran agama dan mendorongnya untuk lebih mendalami dan mempelajari tentang agama. Dia secara giat belajar dan berlatih agar dapat membaca Al-Qur'an dengan fasih (makraj huruf dan tajwidnya benar), menghafal ayat-ayat Al-Qur'an dan do'a-do'a. Sehingga saat ini, dalam kesehariannya selain mengajar di Madrasah Mu'allimin, Bapak Ramlan selalu aktif dalam kegiatan keagamaan di masyarakat. Ia selalu menjadi imam shalat berjamaah di masjid dekat tempat tinggalnya. Ia juga selalu diminta oleh warga masyarakat untuk memimpin pembacaan Yasin, Takhtim dan Tahlil dalam acara do'a selamatan yang diadakan oleh warga masyarakat. ${ }^{37}$

Apa yang tampak dari fenomena yang ditampilkan oleh profil Ramlan di atas, menunjukkan bahwa kemampuan adaptasi (penyesuaian diri) baik secara akademik

${ }^{35}$ Ramlan, Wawancara, Tanggal 17 Februari 2016

${ }^{36}$ Menurut pengakuan salah seorang siswa MTs Mu'allimin, Bapak Ramlan tidak hanya mengajarkan kami tentang pelajaran Fisika, namun ia juga selalu memberikan nasehat-nasehat agama kepada kami. Beliau selalu menagatakan kepada kami "tidak ada gunanya kalian pintar pada mata pelajaran fisika, kalau kalian meninggalkan shalat, karena nanti kalau kalian meninggal dunia shalat itulah yang menjadi bekal kalian di dalam kubur dan di akherat kelak." Muhammad Idris, siswa kelas IX MTs Mu'allimin, Wawancara, Tanggal 17 Februari 2016

${ }^{37}$ Menurut pengakuan ketua pengurus Yayasan Madrasah Mu'allimin, Bapak Ramlan selain sebagai imam di Masjid di sekitar tempat tinggalnya juga aktif dalam kegiatan keagamaan lainnya di tengah masyarakat. Wan Riyadi, Wawancara, Tanggal 17 Februari 2016 
maupun personality merupakan salah satu tipikal perilaku progresif. Apa yang dialami Bapak Ramlan merupakan bukti nyata betapa semangat untuk berubah (maju) melahirkan sebuah tekad yang kuat, membuat seseorang mampu belajar dengan hasil yang melekat kuat. Analisis ini selaras dengan pandangan Dewey bahwa manusia adalah makhluk yang senantiasa berubah dan berkembang sebagaimana tercermin dari ungkapan; " The theory that human nature is unchangable is thus the most depressing and pessimistic of all possible doctrines." ${ }^{38}$ (Bahwa teori yang menyatakan karakter manusia itu tetap, tidak dapat berkembang dan berubah, adalah teori yang amat mengekang dan merupakan doktrin yang bersifat pesimis). Penolakan Dewey terhadap teori tersebut, sebagai bentuk penegesannya bahwa manusia pada dasarnya adalah makhluk progresif.

Fenomena dari perilaku progresif guru di atas menunjukkan adanya cara pandang dan pola pikir guru yang berorientasi ke depan mengikuti perkembangan zaman. Guru dituntut untuk menselaraskan diri dengan perubahan dan kemajuan zaman. Madrasah sebagai lembaga pendidikan yang berbasis agama sudah harus mengalami perubahan dan kemajuan dalam berbagai bidang, tidak hanya dalam bidang keagamaan saja, tetapi juga dalam bidang non keagamaan lainnya, seperti bidang olahraga, kesenian dan lainnya. Berdasarkan dokumentasi dan informasi yang diperoleh, beberapa bidang kegiatan perlombaan olahraga dan kesenian tingkat Kabupaten Rokan Hilir yang pesertanya diikuti oleh siswa-siswa Madrasah Mu'allimin, seperti perlombaan futsal, lari cepat 300 meter, seni tari, perlombaan lagu daerah, dan kepramukaan sebagai perwakilan dari Kecamatan Kubu. ${ }^{39}$

Pendidikan bagian dari realitas zaman akan senantiasa mengalami perubahan seiring dengan perubahan zaman. Sesuai dengan tuntutan perubahan, maka gurupun dituntun untuk memiliki kemampuan dalam penyesuaian-penyesuaian dengan kebutuhan perubahan tersebut. Perubahan dalam kurikulum di antaranya menuntut guru untuk dapat mempersiapkan, melaksanakan dan menyesuaikan berbagai kebutuhan dalam proses belajar mengajar dari sisi pemahaman secara teoritik, keterampilan dalam

\footnotetext{
${ }^{38}$ Dewey, Philosophy of Education (Problem of men), (New Jersey: Littlefield, Adams \& Co. Paterson, 1961), hlm. 191.

${ }^{39}$ Wan Riadi (Pengurus Yayasan), Wan Sri Suryanti, Syafrizal, Wawancara, Tanggal 17 Februari 2016
} 
pelaksanaan pembelajaran sesuai dengan kurikulum yang diberlakukan dan kemampuan untuk melakukan kegiatana evaluasi atas proses yang dilakukannya.

Perilaku guru dalam katagori ini tidak hanya menunjukkan adanya komitmen dan dedikasi yang tinggi terhadap tugas dan tanggung jawab profesinya sebagai guru, tetapi juga menunjukkan adanya kecenderungan peningkatan penguasaan mereka terhadap sejumlah kompetensi yang dipersyaratkan sebagai tenaga profesional, menunjukkan perilaku yang positif terutama berkaitan dengan tugas utama mereka dalam melaksanakan kegiatan pembelajaran di dalam kelas. Hal ini setidaknya dapat dilihat dari dokumentasi yang ada seperti absensi kehadiran guru-guru tersebut, keikutsertaan mereka dalam kegiatan peningkatan profesionlitas mereka seperti menghadiri MGMP, pelatihan dan bimbingan teknis kurikulum 2013, pelatihan dan peningkatan kepala madrasah, begitu pun juga dengan pembuatan RPP, saat penulis cermati terdapat perubahan dan peningkatan dalam penyusunan RPP tersebut, dan lainlainnya.

Apa yang telah dirumuskan dalam RPP tampaknya bukan hanya sekedar memenuhi tuntutan formalitas-administratif, tetapi dibuat dengan sungguh-sungguh dan direalisasikan dalam kegiatan pembelajaran di kelas. Berdasarkan pengamatan di lapangan dan wawancara, dalam kegiatan pembelajaran di kelas terlihat berbagai strategi dan metode yang variatif dilakukan oleh para guru tersebut. Sebagaimana ungkap salah seorang guru:

"Saya selalu menerapkan model pembelajarn agar proses pembelajaran lebih efektif dan semua siswa turut aktif sehingga diharapkan dapat mencapai tingkat kompetensi yang diinginkan. Model pembelajaran yang saya terapkan bagi siswa-siswi tergantung pada materi pembelajaran yang saya berikan. Misalnya materi yang saya ajarkan adalah mengenai drama, maka saya menerapkan model pembelajaran yang sifatnya demonstran atau drama. Kalau materi yang saya ajarkan bersifat analisis dan teoritis maka saya biasanya menerapkan model jigsaw." 40

Guru bertipe ini mengabdikan diri menjadi guru karena menyenanginya. Kemungkinan dia telah memiliki bakat alam, panggilan jiwa, dan kesempatan untuk menjadi seorang guru. Bakat yang dibawa sejak lahir kemudian terasah dengan pengalaman bertahun-tahun. Begitu juga denga pendidikan formal yang telah diterimanya semakin memantapkan keberadaannya sebagai guru. Guru dengan pola ini

${ }^{40}$ Pauh, Wawancara, Tanggal 17 Februari 2016 
selalu belajar dan mengembangkan diri sendiri baik secara berkelompok maupun otodidak dan mandiri. Terlepas apakah ada sumber penghasilan di luar pekerjaannya sebagai guru atau tidak namun imbalan materi tidak menjadi tujuan utama dalam mengajar. Mereka mengajar dengan sukarela dan sarat dengan nilai keikhlasan serta tanggung jawab moral demi kemajuan anak didik sebagai generasi penerus bangsa dan agama.

\section{Kesimpulan}

Dari pemaparan dan uraian di atas, maka dapat disimpulkan bahwa menjadi guru dengan perilaku profesional yang progresif adalah sebuah keniscayaan sebagai upaya meningkatkan mutu dan kualitas pendidikan. Guru progresif memposisikan profesi guru sebagai panggilan jiwa dan tugas mulia dalam rangka memanusiakan manusia. Berangkat dari konsepsi ini, mendorongnya untuk lebih kreatif dan inovatif terutama dalam melaksanakan kegiatan pembelajaran di kelas. Anak didik tidak hanya diposisikan sebagai objek, tetapi juga sebagai subjek yang dinamis, selain memiliki berbagai potensi, bakat dan kemampuan juga memiliki perasaan dan keinginankeinginan.

Situasi dan kondisi objektif yang kurang menunjang efektifitas dari profesionalitas guru, tidak menjadi hambatan bagi guru progresif untuk meningkatkan perilaku profesionalnya. Demikian halnya dengan tuntutan dari perubahan dan perkembangan zaman serta keinginan masyarakat, membuatnya untuk senantiasa berusaha menselaraskan sikap dan perilakunya. Di sisi lain, perilaku guru yang progresif juga amat selaras dengan konsep human atau fitrah kemanusiaan yang dinamis dan fleksibel.

Sebagai implikasi dari penelitian ini, lembaga-lembaga yang mencetak guru (LPTK) untuk lebih mengembangkan pola-pola perkuliahan yang berorientasi kepada fitrah kemanusiaan yaitu dinamis-fleksibel dan menjadikannya sebagai paradigma demi membangun dan menumbuhkan daya kreativitas di kalangan mahasiswa sebagai calon guru. Karena secara teknis dan kondisi objektif di dunia pendidikan akan terus berubah dan berubah selaras dengan perkembangan masyarakat dan zaman. 


\section{Daftar Kepustakaan}

Abd. Rachman Assegaf, Filsafat Pendidikan Islam; Paradigma Baru Pendidikan Hadhari Berbasis Integratif-Interkonektif, Jakarta: PT. Raja Grafindo, 2011

Abdurrahman Mas'ud, Menggagas Format Pendidikan Non Dikotomik, Yogyakarta: Gama Media, 2002.

Ahmad S. M, Tathawwur al-Fikry al-Tarbawy, Kairo: Matabi’ Sabjal al-Arabi,1975).

A. Qodri Azizy, Melawan Globalisasi, Yogyakarta: Pustaka Pelajar, 2003

Dedi Supriadi, Mengangkat Citra dan Martabat Guru, Yogyakarta: Adicita Karya Nusantara, 1998

Dewey, Philosophy of Education (Problem of men), New Jersey: Littlefield, Adams \& Co. Paterson, 1961

Hernowo, Menjadi Guru yang Mau dan Mampu Mengajar Secara Menyenangkan, Bandung: Penerbit MLC, 2005

John M. Echols dan Hassan Shadily, Kamus Inggris - Indonesia, An English-Indonesian Dictionary, Diedit dan Direvisi oleh John U. Wolff dan James T. Collins bekerjasama dengan Hassan Shadily, Jakarta: PT. Gramedia, 1992

Lester D. Crow dan Alice Crow, Educational Psychology, New York: American Book Company, 1958

Muhammad Nur Abdul Hafizh Suwaid, Prophetic Parenting, Cara Nabi SAW mendidik Anak, Yogyakarta: Pro-U Media, 2010

Munif Chatib, Sekolahnya Manusia, Sekolah Berbasis Multiple Intelligences di Indonesia, Bandung: PT Mizan Pustaka, 2009

UU No. 14 Tahun 2005 tentang Guru dan Dosen.

Yatim Rianto, Pradigma Baru Pembelajaran, Jakarta: Prenada Media Group, 2009 